\title{
Culicoides (Avaritia) gornostaevae Mirzaeva, 1984 (Diptera: Ceratopogonidae) - a possible vector species of the Obsoletus group new to the European fauna
}

\author{
Carsten Kirkeby $^{1 *}$ and Patrycja Dominiak ${ }^{2}$
}

\begin{abstract}
Background: Culicoides gornostaevae Mirzaeva, 1984, known previously only from Siberia, is a boreal species included into the Obsoletus group of Culicoides sg. Avaritia. Members of the subgenus can act as vectors of various diseases. In Europe they are involved in the transmission of the Schmallenberg virus and bluetongue virus.

Findings: Culicoides gornostaevae Mirzaeva, 1984 is reported for the first time in Europe with new country records from Norway, Poland and Sweden.

Conclusions: Culicoides gornostaevae Mirzaeva, 1984 has not been previously mentioned from Europe, even though there has been an extensive monitoring of Culicoides species during the last decades. Most probably this species has been notoriously overlooked in the materials, because of the problems with identification of the females of the subgenus Avaritia. Similar to other species of the Obsoletus group, C. gornostaevae should be regarded as a possible vector for Schmallenberg and bluetongue virus.
\end{abstract}

Keywords: Diptera, Ceratopogonidae, Culicoides, Obsoletus group, New records, Europe

\section{Findings}

\section{Background}

There are over 1300 extant species of Culicoides in the world fauna [1], but only approximately 30 are known to act as vectors for diseases [2]. Fourteen of these vector species are placed in the subgenus Avaritia [2], and among them are also some Culicoides of the Obsoletus group. Three of the six species included into this species group [3] have been previously recorded in Europe: C. montanus Shakirzjanova, 1962, C. obsoletus (Meigen, 1818) and C. scoticus Downes \& Kettle, 1952. However, males of $C$. montanus have never been collected and observed [3]. The remaining three species of the Obsoletus group are C. gornostaevae Mirzaeva, 1984 and C. sinanoensis Tokunaga, 1937, which have been recorded from Russia and eastwards to Japan [4], and a North

\footnotetext{
*Correspondence: ckir@vet.dtu.dk

${ }^{1}$ National Veterinary Institute, Technical University of Denmark, Bülowsvej 27, DK-1870 Frederiksberg C, Denmark

Full list of author information is available at the end of the article
}

American species C. sanguisuga (Coquillett, 1901). Since the outbreak of bluetongue virus in northern Europe in 2006, a lot of research has been focused on the females of Culicoides midges and on their role as vectors. Males in the Obsoletus group are easy to distinguish by the shape of the genitalia, but the females are notoriously difficult to separate by morphology. Therefore, molecular analyses have been conducted to identify specimens to the species level, but it is often not possible to examine the whole amount of materials in large monitoring programmes for vectors. Thus, it is probable that in some cases female specimens of this group could have been misidentified, especially if the species considered have been chosen by geography only. Moreover, it is noteworthy that an intense monitoring of potential vector species during the last decades has mostly focused on vectors near farms, hence the potential vector species in other habitats that affect wildlife species such as roe deer and red deer may have been overlooked $[5,6]$. 
We here report findings of Culicoides gornostaevae from Norway, Poland and Sweden for the first time.

The division into the zoogeographic regions follows Holt et al. [7].

\section{Systematics}

\section{Culicoides gornostaevae Mirzaeva}

Culicoides sanguisuga: Gornostaeva 1977 [8]: 493 (Russia).

Nec C. sanguisuga (Coquillet, 1901).

Culicoides gornostaevae Mirzaeva, 1984 [9]: 371 (Russia).

Culicoides (Avaritia) gornostaevae: Mirzaeva 1989

[10]: 62 (Russia); Glukhova 1989 [4]: 187 (Russia);

Mirzaeva 2000 [11]: 422 (Russia); Glukhova 2005 [12]: 12, 17 (in key).

Culicoides obsoletus: Hagan et al. 2000 [13]: 469 (Norway). Nec C. obsoletus (Meigen, 1818).

\section{New country records}

Norway SW. Geitaknottane, Kvam municipality in Hordaland County $\left(60.05^{\circ} \mathrm{N} 5.53^{\circ} \mathrm{E}, 180-200\right.$ m.a.s.l.), coastal forest, 28 May 1998, fogging, 1 male, leg. J. Skartveit \& K.H. Thunes. Poland N. Brzyno n. Wejherowo, umbelliferae flowers, 2 June 1982, 1 male, leg. R. Szadziewski. Gdańsk, zoological garden, 1 June 1979, at light, 1 male. Poland NE. Silec n. Kętrzyn, 8 June 1980, near forest margin, swarming, 7 males, leg. R. Szadziewski. Poland S. Orava-Nowy Targ Basin, Czarny Dunajec Baligówka, umbelliferae flowers, 27 June 2006, net, 2 males, leg. P. Dominiak. Poland SE. Ustrzyki Górne, 29 July 1980, swarming, 1 male, leg. R. Szadziewski. Sweden S. Vivljunga n. Markaryd $\left(56.58501^{\circ} \mathrm{N}\right.$ $13.48143^{\circ} \mathrm{E}$ ), 7 June 2014, swarming, 3 males, leg. C. Kirkeby. These specimens were caught in a mixed swarm with $C$. impunctatus females.

\section{Distribution and feeding habits}

Culicoides gornostaevae is a boreal Palaearctic species, widely distributed in the western and middle part of

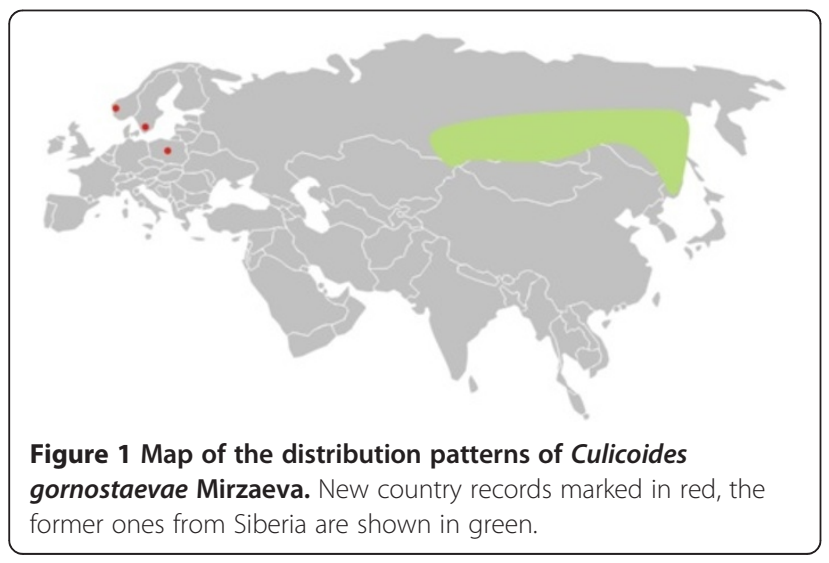

Siberia, between the Uba River and the Amur River (Figure 1). According to data from the literature it is especially numerous in the forest zone of Altai, Khakassia, Gornaya Shoria and Western Sayan. However, it is important to indicate that almost all of the former records are based on females only. This biting midge species is new for the fauna of Norway, Poland and Sweden. Females of C. gornostaevae are known to attack humans and other animals [4].

\section{Morphology}

Culicoides gornostaevae closely resembles C. obsoletus, but these two species show clear differences in male genitalia armature. Males of C. gornostaevae (Figure 2) are characterized by widely opened triangular or nearly slit-like excavation of the distal margin of the 9th sternite (Figure 3a-d), and by bare tips of parameres (Figure 4d). The cleft of the 9th sternite in C. obsoletus is oval with distinctly converging distal edges (Figure $3 e-h$ ), while tips of parameres are covered with short but prominent hair (Figure 4e). The shape of aedeagus is similar in both species and often depends on different orientation of specimens after mounting them on a microscope slide. However, apicolateral parts of the aedeagal arch seems to be rather angular or trapezoidal in C. gornostaevae (Figure 4a,b) and more rounded in C. obsoletus (Figure 4c). A transparent membrane attached to the apical projection of aedeagus (sometimes referred to as spines or teeth), which is usually mentioned as a characteristic feature for male of $C$. gornostaevae only $[4,8-10,12]$, even if sometimes not clearly visible, is always present in both species. We do not find distribution and intensity of wing patterns as useful in morphological identification of the species of the Obsoletus group, at least in males. These

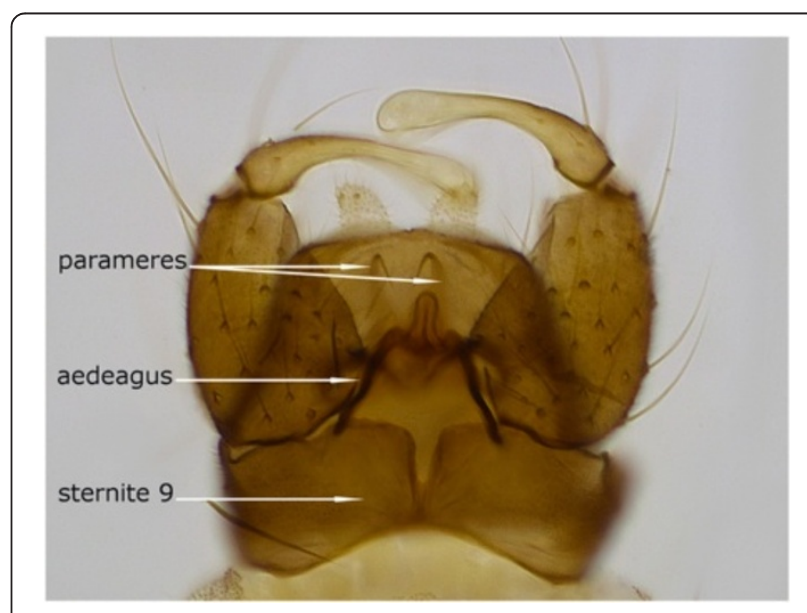

Figure 2 Male genitalia of Culicoides gornostaevae Mirzaeva, ventral view. Specimen from Poland. 


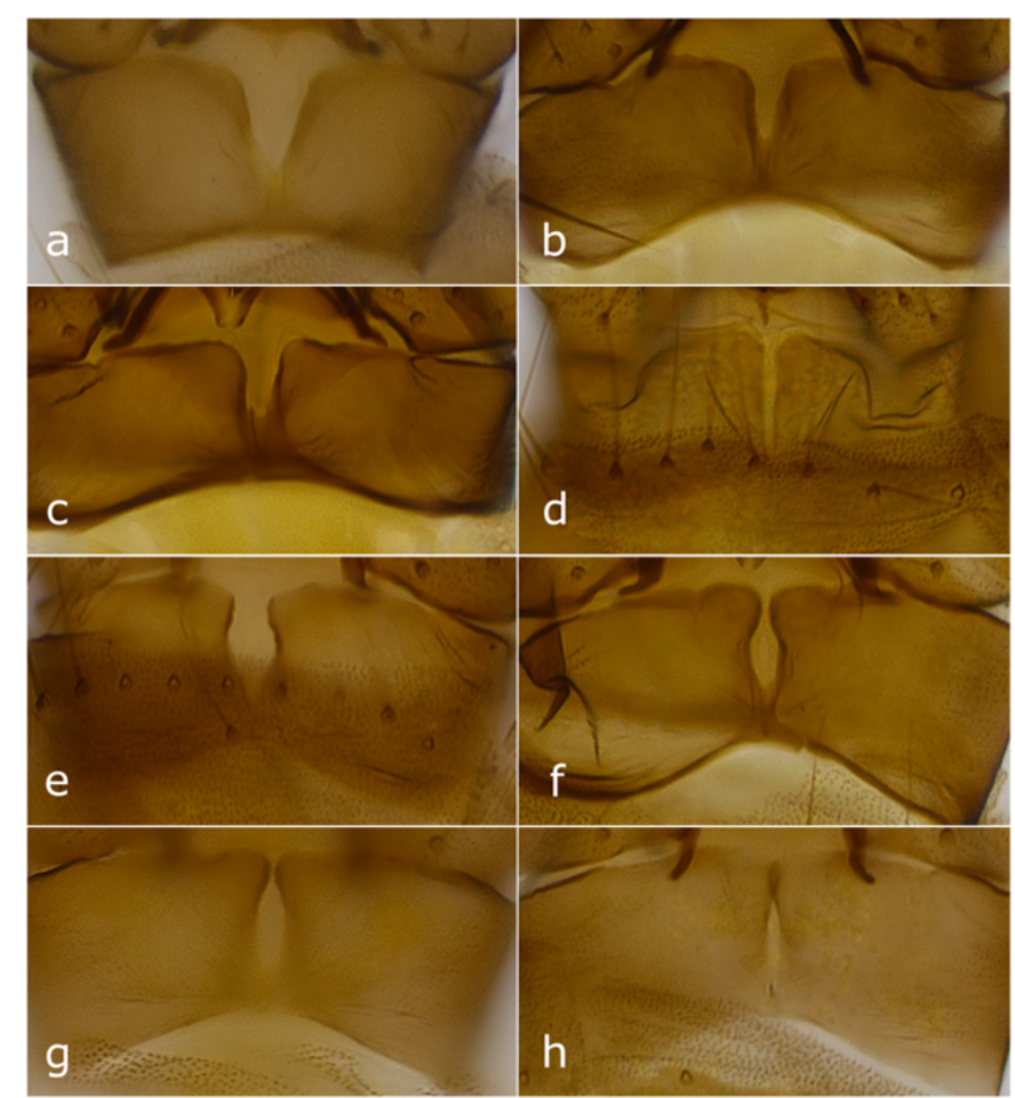

Figure 3 Sternite 9 in male genitalia of Culicoides gornostaevae Mirzaeva (a-d) and C. obsoletus (Meigen) (e-h), ventral view. Specimens of C. gornostaevae from: a - Sweden; b, c - Poland; d - Norway.

characters are highly variable, and among material examined both specimens with well visible wing patterns as well as those with very pale, indistinct patterns were present.

Although females of the subgenus Avaritia have nearly no diagnostic features, and thus are easily misidentified, the descriptions of some species are based only on this sex. Among them are Culicoides sanguisuga known from the Nearctic and C. montanus, originally described from montane regions in Kazakhstan but reported from both the Palaearctic and the SaharoArabian regions. The first detailed illustrations of males of these two species can be found in Jamnback \& Wirth [14] (or in [15]) and in Gutsevich [16] (the same drawing was subsequently used in $[9,10,17]$ ) respectively. It is probable that the names C. gornostaevae and C. sanguisuga, and maybe also C. montanus, should be treated as synonyms, but further studies, including a molecular analysis, and examination of more materials are necessary to confirm this supposition. Male genitalia of the two first mentioned species look very much alike, but according to Mirzaeva's [9] description of
C. gornostaevae, wings in this species are a little bit darker and have less prominent color patterns in comparison to those in C. sanguisuga. The diagnostic characters given by Gutsevich [16] for male C. montanus are based probably on a single specimen. According to this paper (ibidem) the sensory pit on 3rd palpal segment is rather deep. The aedeagal arch in male genitalia of this species seems to be quite slender (similar to this in C. obsoletus), but the shape of the cleft in sternite 9 as well as bare tips of parameres indicate that C. montanus is very close to C. gornostaevae. Female of C. montanus is characterized by a stout 3rd palpal segment bearing a deep sensory pit $[4,9,10,16-18]$ and by the presence of peg-like sensilla on proximal flagellomeres $[4,9,10,16,17]$.

\section{Discussion}

Delimitation of the species within the Obsoletus group still remains problematic, and females are especially difficult to distinguish by morphology [19]. There are no proper diagnostic characters for female of Culicoides gornostaevae, therefore, this species may have 


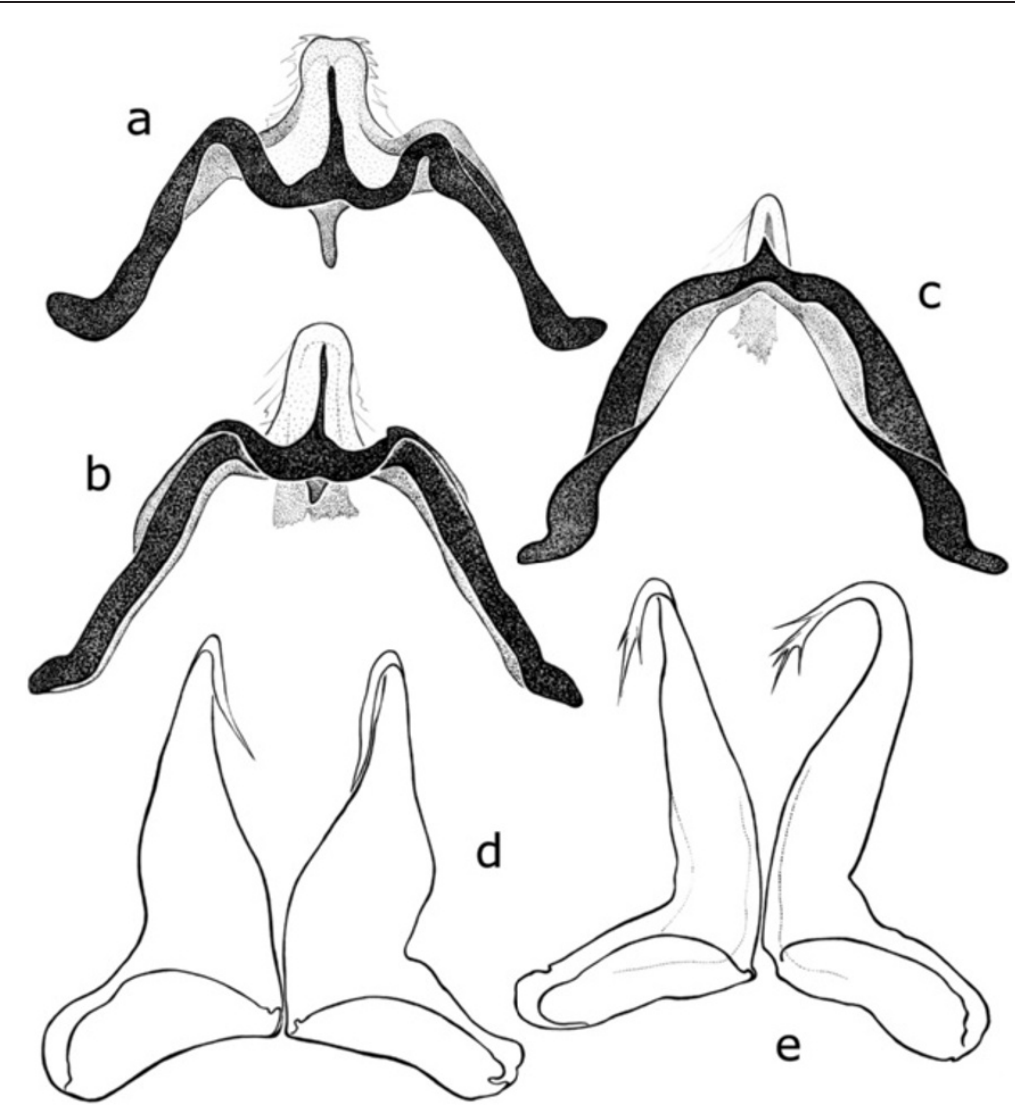

Figure 4 Aedeagus (a-c) and parameres (d, e) in male genitalia of Culicoides gornostaevae Mirzaeva (a, b, d) and C. obsoletus (Meigen) (c, e). Specimens of C. gornostaevae from: a-Norway, b-Poland, d-Poland.

been identified as $C$. obsoletus and overlooked in trap catches. Furthermore, the males are usually not caught in large numbers in light traps, and it could be the explanation why this species has not been reported in any previous studies concerned with the Culicoides midges in Europe. The present records are based on males collected between 1979 and 2014, which indicates that this species is well established here. Because many of the Culicoides species of the subgenus Avaritia are known to transmit various diseases, and due to its close relationship to C. scoticus and C. obsoletus, C. gornostaevae should also be regarded as a potential vector of bluetongue virus or Schmallenberg virus in Europe.

\section{Conclusion}

We here report the first records of Culicoides gornostaevae from Norway, Poland and Sweden. This species is morphologically close to C. obsoletus but these both species differ in the armature of the male genitalia. Culicoides gornostaevae belongs to the subgenus Culicoides (Avaritia), and similarly to C. scoticus and
C. obsoletus, should be considered as possible vector species of bluetongue virus and Schmallenberg virus in Europe.

\section{Competing interests}

The authors declare that they have no competing interests.

\section{Author contributions}

CK collected the specimens in Sweden, coined the idea for the manuscript and wrote the first draft. PD identified the species, added the other previously unpublished records, wrote the sections Morphology and Distribution and feeding habits, and produced the figures. Both authors read and approved the final version of the manuscript.

\section{Acknowledgements}

This study was funded by EU grant GOCE-2003-010284 EDENext and is catalogued by the EDENext Steering Committee as EDENext 253 (http://www. edenext.eu). The contents of this publication are the sole responsibility of the authors and do not necessarily reflect the views of the European Commission. The first author thanks René Bødker (DTU VET) and Jan Chirico (SVA) for comments on the manuscript. The second author thanks Ryszard Szadziewski (University of Gdańsk) for his help in identification of the Culicoides species.

\section{Author details}

${ }^{1}$ National Veterinary Institute, Technical University of Denmark, Bülowsvej 27, DK-1870 Frederiksberg C, Denmark. ${ }^{2}$ Department of Invertebrate Zoology and Parasitology, University of Gdańsk, Wita Stwosza 59, 80-308 Gdańsk, Poland. 


\section{References}

1. Borkent A: World species of biting midges (Diptera: Ceratopogonidae). Available from: http://www.inhs.uiuc.edu/cee/FLYTREE/

CeratopogonidaeCatalog.pdf (last updated: 20 January 2014).

2. Meiswinkel R, Gomulski LM, Delécolle J-C, Goffredo M, Gasperi G: The taxonomy of Culicoides vector complexes-unfinished business. Vet Ital 2004, 40(3):151-159.

3. Garros C, Mathieu B, Balenghien T, Cêtre-Sossah C, Delécolle J-C: Suggesting synonymies? Comments on Kiehl et al. (2009) "the European vectors of Bluetongue virus: are there species complexes, single species or races in Culicoides obsoletus and C. pulicaris detectable by sequencing ITS-1, ITS-2 and 18S-rDNA?" Parasitol Res 2010, 107(3):731-734.

4. Glukhova VM: Blood-sucking midges of the genera Culicoides and Forcipomyia (Ceratopogonidae). Fauna USSR 1989, 139(3(5a)):408. in Russian.

5. Ruiz-Fons F, Reyes-García ÁR, Alcaide V, Gortázar C: Spatial and temporal evolution of bluetongue virus in wild ruminants. Spain Emerg Infect Dis 2008, 14(6):951.

6. Lindén A, Grégoire F, Nahayo A, Hanrez D, Mousset B, Massart AL, Leeuw ID, Vandemeulebroucke E, Vandenbussche F, De Clercq K: Bluetongue virus in wild deer, Belgium, 2005-2008. Emerg Infect Dis 2010, 16(5):833.

7. Holt BG, Lessard JP, Borregaard MK, Fritz SA, Araújo MB, Dimitrov D, Fabre P-H Graham CH, Graves GR, Jønsson KA, Nogués-Bravo D, Wang Z, Whittaker RJ, Fjeldså J, Rahbek C: An Update of Wallace's Zoogeographic Regions of the World. Science 2013, 339:74.

8. Gornostaeva RM: Culicoides (Avaritia) sanguisuga, a new species of biting midges for the fauna of the USSR. Parazitologiia 1977, 11(6):493-498 in Russian.

9. Mirzaeva AG: A review of biting-midges of the subgenus Avaritia Fox (Diptera, Ceratopogonidae, genus Culicoides Latr.) from Siberia. Ent Obozr 1984, 63:365-378. in Russian, English summary.

10. Mirzaeva AG: The bloodsucking midges of Siberia and the (Soviet) Far East. Novosibirsk "NAUKA" Siberian Division, Akademiia Nauk SSSR, Sibirskoe Otdelenie, Biologicheskii Institut 1989, 232. in Russian.

11. Mirzaeva AG: Concerning swarming of males of blood-sucking Culicoides from subgenus Avaritia (Ceratopogonidae). Sib Ekolog Zh 2000, 4:419-423. in Russian, English summary.

12. Glukhova VM: Culicoides (Diptera, Ceratopogonidae) of Russia and adjacent lands. Int J Dipterol Res 2005, 16:3-75.

13. Hagan DV, Hassold E, Kynde B, Szadziewski R, Thunes KH, Skartveit J, Grogan WL Jr: Biting midges (Diptera: Ceratopogonidae) from forest habitats in Norway. Pol J Entom 2000, 69:465-476.

14. Jamnback H, Wirth WW: The species of Culicoides related to obsoletus in eastern North America (Diptera: Ceratopogonidae). Ann Entomol Soc Am 1963, 56(2):185-198.

15. Jamnback H: The Culicoides of New York State (Diptera: Ceratopogonidae). Bull New York State Mus Sci Serv 1965, 399:1-154.

16. Gutsevich AV: Keys to bloodsucking midges of the genus Culicoides from Middle Asia. Ent Obozr 1966, 45(3):658-676 in Russian.

17. Gutsevich AV: The bloodsucking midges (Ceratopogonidae). Fauna SSSR 1973, 3(5):270. in Russian.

18. Shakirzjanova MC: New species of Culicoides (Diptera, Heleidae) from Kazakhstan. Tr Inst Zool Akad Nauk Kaz SSR (Alma Ata) 1962, 18:254-259. in Russian.

19. Augot D, Sauvage F, Jouet D, Simphal E, Veuille M, Couloux A, Kaltenbach ML, Depaquit J: Discrimination of Culicoides obsoletus and Culicoides scoticus, potential bluetongue vectors, by morphometrical and mitochondrial cytochrome oxidase subunit I analysis. Infec Genets Evol 2010, 10(5):629-637.

doi:10.1186/1756-3305-7-445

Cite this article as: Kirkeby and Dominiak: Culicoides (Avaritia) gornostaevae Mirzaeva, 1984 (Diptera: Ceratopogonidae) - a possible vector species of the Obsoletus group new to the European fauna. Parasites \& Vectors 2014 7:445.

\section{Submit your next manuscript to BioMed Central and take full advantage of:}

- Convenient online submission

- Thorough peer review

- No space constraints or color figure charges

- Immediate publication on acceptance

- Inclusion in PubMed, CAS, Scopus and Google Scholar

- Research which is freely available for redistribution 